\title{
TINGKAT KETAHANAN PANGAN PADA RUMAH TANGGA MISKIN DI DAERAH RAWAN BANJIR (Studi di Desa Tanjang dan Desa Kosekan Kecamatan Gabus Kabupaten Pati)
}

FOOD SECURITY LEVEL OF POOR HOUSEHOLDS IN FLOOD VULNERABLE AREA

(Study in Tanjang Village and Kosekan Village Gabus Subdistrict Pati Regency)

\author{
Herna Octivia Damayanti \\ Badan Perencanaan Pembangunan Daerah Kabupaten Pati \\ Email : Octivia_oc@yahoo.co.id
}

Naskah Masuk: 25 Pebruari 2018

Naskah Revisi: 5 April 2018

Naskah Diterima: 7 April 2018

\begin{abstract}
Food security is a key issue in the fulfillment of people's welfare. The condition of food insecurity that can be called vulnerable food is experienced mostly by the poor. Besides economic factors, food insecurity can occur in flood vulnerable area. Objectives of the research are: (1) to analyze the food security level in the poor households; and (2) to analyze the inequality of food security. This quantitative descriptive research was conducted between March and September 2017 in Tanjang village and Kosekan village, Gabus Subdistrict, Pati regency. Sampling size is 89 households consisting of 41 households in Kosekan village and 48 households in Tanjang village. Data analysis: (1) food security with Current Population Survei (CPS) Food Security Suplement and (2) the inequality of food security statistically. Results of the research: (1) the food security index of poor households in Tanjang and Kosekan villages can be categorized as food resistant households; and (2) the level of food inequality of Tanjang and Kosekan villages were similar or not significantly different.
\end{abstract}

Keywords: CPS food security suplement, flood vulnerable area, food security, poor households

\begin{abstract}
ABSTRAK
Ketahanan pangan merupakan isu pokok dalam pemenuhan kesejahteraan masyarakat. Kondisi tidak tahan pangan disebut juga rawan pangan banyak dialami oleh golongan masyarakat atau rumah tangga miskin. Selain karena faktor ekonomi, kerawanan pangan dapat terjadi di daerah rawan banjir. Tujuan penelitian : (1) menganalisis tingkat ketahanan pangan rumah tangga miskin; (2) menganalisis ketimpangan ketahanan pangan. Penelitian deskriptif kuantitatif ini dilakukan bulan Maret-September 2017 dengan lokasi di Desa Tanjang dan Desa Kosekan Kecamatan Gabus Kabupaten Pati. Jumlah sampel Desa Kosekan 41 KK dan Desa Tanjang 48 KK. Analisis data : (1) ketahanan pangan dengan Current Population Survei (CPS) Food Security Suplement dan (2) ketimpangan ketahanan pangan rumah tangga miskin secara statistik. Hasil penelitian yaitu (1) indeks ketahanan pangan rumah tangga miskin di Desa Tanjang dan Desa Kosekan termasuk kategori rumah tangga tahan pangan dan (2) tingkat ketimpangan pangan Desa Tanjang dan Desa Kosekan sama atau tidak berbeda nyata (tidak signifikan).
\end{abstract}

Kata kunci : CPS food security suplement, ketahanan pangan, daerah rawan banjir, rumah tangga miskin 


\section{PENDAHULUAN}

Ketahanan pangan merupakan isu pokok dalam pemenuhan kesejahteraan masyarakat karena akan menentukan kestabilan ekonomi, sosial, dan politik dalam suatu negara (Nurhemi dkk, 2014). Mempertahankan ketahanan pangan di tingkatan nasional dan rumah tangga masih menjadi tantangan utama bagi negara-negara berkembang. Berdasarkan the Food and Agriculture Organization (FAO), sekitar 870 juta orang diperkirakan kurang gizi (dalam hal pasokan energi makanan) pada periode 2010-2012. Angka ini mewakili 12,5\% dari populasi global. Sebagian besar dari mereka, 852 juta tinggal di negara-negara berkembang, di mana prevalensi kekurangan gizi sekarang diperkirakan pada $14,9 \%$ dari populasi (Zakari et al, 2014).

FAO mendefinisikan keamanan pangan sebagai suatu situasi "ketika orang, setiap saat, memiliki akses fisik dan ekonomi, makanan yang aman dan bergizi untuk memenuhi kebutuhan makanan dan preferensi makanan mereka untuk kehidupan yang aktif dan sehat". Menurut definisi ini, ada tiga komponen penting yang saling terkait keamanan pangan: ketersediaan, akses dan pemanfaatan. Oleh karena itu, rumah tangga dikatakan tahan pangan jika dalam jangka waktu tertentu memiliki makanan yang cukup (makanan yang biasa disajikan dalam sehari) untuk anggotanya untuk seluruh periode. Kalau tidak, rumah tangga itu tidak aman pangan (Zakari et al, 2014). UndangUndang Nomor 18 Tahun 2012 tentang Pangan mengamanatkan bahwa negara berkewajiban mewujudkan ketersediaan, keterjangkauan, dan pemenuhan konsumsi pangan yang cukup, aman, bermutu, dan bergizi seimbang, baik pada tingkat nasional maupun daerah hingga perseorangan secara merata di seluruh wilayah Negara Kesatuan Republik Indonesia sepanjang waktu dengan memanfaatkan sumber daya, kelembagaan, dan budaya lokal.

Kebalikan dari ketahanan pangan adalah rawan pangan. Kerawanan pangan terjadi manakala rumah tangga mengalami ketidakcukupan pangan untuk memenuhi standar kebutuhan fisiologis bagi pertumbuhan dan kesehatan para individu anggotanya. Ada tiga hal penting yang mempengaruhi tingkat rawan pangan, yaitu kemampuan penyediaan pangan kepada individu, kemampuan individu atau rumah tangga untuk mendapatkan pangan, dan proses distribusi dan pertukaran pangan yang tersedia dengan sumberdaya yang dimiliki oleh individu atau rumah tangga (Sumarmi dalam Ermawati, 2011). Kerawanan pangan rumah tangga terjadi saat kondisi ketahanan pangan tidak terpenuhi dan anggota keluarga dalam rumah tangga tidak mampu memperoleh pangan yang seimbang (Association of Maternal and Child Health Programs, 2013).

Salah satu golongan masyarakat yang rawan pangan adalah rumah tangga miskin. Kemiskinan akan sangat berpengaruh pada ketahanan pangan karena rumah tangga miskin tidak mampu menyediakan pangan dalam jumlah yang cukup, aman dan bergizi baik dengan memproduksi sendiri maupun membeli. Selain karena faktor ekonomi, kerawanan pangan dapat terjadi karena adanya bencana alam seperti banjir. Hal ini dikarenakan terbatasnya akses terhadap pangan, sehingga akan berpengaruh pada ketahanan pangan rumah tangga miskin yang tinggal di daerah rawan banjir (Ermawati, 2011).

$$
\text { Berdasarkan laporan Badan }
$$

Penanggulangan Banjir Daerah (BPBD) Kabupaten Pati tentang bencana banjir tanggal 13 Februari 2017, salah satu 
daerah yang terkena banjir cukup luas adalah Kecamatan Gabus. Berdasarkan peta daerah rawan banjir, 23 desa dari 24 desa di Kecamatan Gabus masuk kategori kerawanan banjir tinggi (BPBD Kab. Pati, 2016).

Daerah dengan tingkat kerawanan banjir tinggi dan membutuhkan waktu lebih lama untuk surut banjir terutama berada di sepanjang aliran Sungai Juwana yaitu Desa Wuwur, Karaban, Kosekan, Tanjang, Gempolsari, Banjarsari dan Mintobasuki. Berdasarkan informasi dari BPBD Kab. Pati bahwa di Kecamatan Gabus terdapat Desa Tangguh Bencana (Destana) yaitu Desa Mintobasuki, Banjarsari dan Kosekan. Dalam penelitian ini, lokasi penelitian berada di Desa Kosekan untuk mewakili Desa Tangguh Bencana dan Desa Tanjang untuk mewakili Bukan Desa Tangguh Bencana. Berdasarkan latar belakang tersebut, maka tujuan penelitian ini adalah (1) menganalisis tingkat ketahanan pangan rumah tangga miskin di Desa Kosekan dan Desa Tanjang; (2) menganalisis ketimpangan ketahanan pangan yang terjadi antara Desa Kosekan dan Desa Tanjang.

\section{TINJAUAN PUSTAKA}

\section{Ketahanan Pangan}

Konsep ketahanan pangan yang disepakati secara internasional dalam World Conference on Human Right 1993 dan World Food Summit 1996 adalah kondisi terpenuhinya kebutuhan gizi setiap individu baik dalam jumlah maupun mutu agar dapat hidup aktif dan sehat secara berkesinambungan sesuai dengan budaya setempat (Rosyadi \& Purnomo, 2012).

UU No. 18 Tahun 2012 menyebutkan ketahanan pangan adalah kondisi terpenuhinya Pangan bagi negara sampai dengan perseorangan, yang tercermin dari tersedianya Pangan yang cukup, baik jumlah maupun mutunya, aman, beragam, bergizi, merata, dan terjangkau serta tidak bertentangan dengan agama, keyakinan, dan budaya masyarakat, untuk dapat hidup sehat, aktif, dan produktif secara berkelanjutan.

\section{Kemiskinan}

Hasan \& Saputra (2008) menyatakan bahwa secara tidak langsung kemiskinan menjadi indikasi akan lemahnya tahap penggunaan pangan akibat dampak tidak meratanya distribusi pendapatan dan seterusnya menjadikan mereka sebagai komunitas yang rawan pangan.

Menurut Sumarwan dan Sukandar dalam Ermawati (2011), kemiskinan sangat terkait dengan kemampuan keluarga untuk memenuhi kebutuhan pokoknya, yaitu pangan. Mereka yang dikategorikan miskin adalah keluarga yang rawan pangan atau tidak tahan pangan karena tidak mengkonsumsi pangan yang cukup. Selain karena daya beli yang rendah, pengetahuan tentang gizi rumah tangga miskin rendah, sehingga dalam mengkonsumsi makanan mereka kurang mempertimbangkan kandungan gizi pada makanan.

\section{METODE PENELITIAN}

Penelitian ini merupakan penelitian deskriptif dengan pendekatan kuantitatif. Penelitian dilakukan pada bulan Maret-September 2017 dengan lokasi penelitian di Desa Tanjang dan Desa Kosekan Kecamatan Gabus Kabupaten Pati. Data yang digunakan berupa data primer dan data sekunder. Data primer diperoleh dari responden melalui kuesioner, sedangkan data sekunder berupa dokumen yang berasal dari instansi terkait.

Sampel penelitian yaitu rumah tangga miskin di Desa Kosekan dan Desa Tanjang. Data rumah tangga miskin di lokasi penelitian berasal dari Basis Data 
Terpadu-Tim Nasional Percepatan Penanggulangan Kemiskinan (BDTTNP2K) tahun 2016. Penentuan sampel penelitian dengan menggunakan nomogram Harry King dengan tingkat kesalahan 10\%. Desa Kosekan diperoleh jumlah sampel sebesar $31 \%$ dari total populasi 131 Kepala Keluarga (KK) sehingga jumlah sampel menjadi $41 \mathrm{KK}$. Desa Tanjang diperoleh jumlah sampel sebesar $24 \%$ dari total populasi $199 \mathrm{KK}$ sehingga jumlah sampel menjadi $48 \mathrm{KK}$. Metode pengambilan sampel dengan simple random sampling.

Teknik analisis data yang digunakan adalah analisis kualitatif dengan Current Population Survey (CPS) Food Security Suplement. Metode ini adalah suatu metode yang digunakan untuk mengetahui bagaimana tingkat ketahanan pangan dalam rumah tangga. Metode ini telah digunakan oleh United States Census Bureau untuk mengetahui level ketahanan pangan rumah tangga di United States baik pada tingkat nasional maupun negara bagian (Widayaningsih, 2012).

Ketahanan pangan keluarga diukur dengan cara menanyakan beberapa pertanyaan penting mengenai kondisi rumah tangga, peristiwa, kebiasaan dan reaksi subjektif (Widayaningsih, 2012). Setiap butir pertanyaan disediakan 4 jawaban yaitu skor 0 untuk Tidak Pernah; skor 1 untuk Kadang-kadang; skor 2 untuk Sering dan skor 3 untuk Selalu. Skor terendah yang diperoleh adalah 0 , sedangkan skor tertinggi yang diperoleh adalah 54. Selanjutnya jawaban responden diberikan skor dan diindeks menggunakan rumus sebagai berikut :

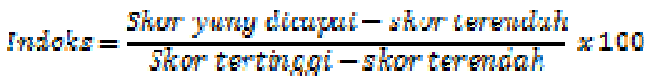

Tingkat ketahanan pangan secara kualitatif, diperoleh berdasarkan jawaban responden, yaitu: a). Rumah tangga tahan pangan: rumah tangga berdasarkan survei yang diajukan tidak terdapat indikasi terjadinya rawan pangan, memiliki indeks antara 0-24.

b). Rumah tangga rawan pangan tanpa kelaparan: rumah tangga berdasarkan survei yang diajukan memiliki beberapa indikator terjadinya rawan pangan, terdapat sedikit atau tidak sama sekali indikator terjadinya kelaparan, memiliki indeks antara 2550.

c). Rumah tangga rawan pangan dengan tingkat kelaparan sedang: rumah tangga berdasarkan survei yang diajukan memiliki lebih banyak indikator terjadinya rawan pangan, terdapat lebih dari satu indikator terjadinya kelaparan pada anggota keluarga yang berusia dewasa, memiliki indeks antara 51-75.

d). Rumah tangga rawan pangan dengan tingkat kelaparan lebih parah: rumah tangga berdasarkan survei yang diajukan memiliki lebih banyak indikator terjadinya rawan pangan, terdapat indikator terjadinya kelaparan pada anggota keluarga baik yang berusia anak-anak, bahkan terdapat indikator kelaparan yang lebih parah pada anggota keluarga yang berusia dewasa, memiliki indeks antara 75-100.

Ketimpangan ketahanan pangan rumah tangga miskin di Desa Kosekan dan Desa Tanjang dianalisis secara statistik. Hipotesis uji sebagai berikut :

$\mathrm{H}_{0}$ : tingkat ketahanan pangan Desa Kosekan sama (tidak berbeda nyata atau tidak signifikan) dengan tingkat ketahanan pangan Desa Tanjang.

$\mathrm{H}_{1}$ : tingkat ketahanan pangan Desa Kosekan tidak sama (berbeda nyata atau signifikan) dengan ketahanan pangan Desa Tanjang. 
Dasar pengambilan keputusan adalah (a) Jika probabilitas (sig) < 0,05, maka $\mathrm{H}_{0}$ diterima; (b) Jika probabilitas (sig) > 0,05, maka $\mathrm{H}_{0}$ ditolak.

\section{HASIL DAN PEMBAHASAN}

\section{Karakteristik Rumah Tangga Responden}

Karakteristik rumah tangga responden adalah kondisi atau keadaan spesifik rumah tangga yang berkaitan langsung dengan dirinya (Fathonah dkk, 2011). Karakteristik rumah tangga pada penelitian ini yaitu berdasarkan usia, jenis kelamin, tingkat pendidikan, pendapatan dan status kepemilikan rumah. Karakteristik rumah tangga responden berdasarkan usia kepala rumah tangga disajikan pada Tabel 1.

Tabel 1.

Karakteristik Rumah Tangga Responden Berdasarkan Usia Kepala Rumah Tangga

\begin{tabular}{lrrrrr}
\hline \multirow{2}{*}{$\begin{array}{c}\text { Karakteristik } \\
\text { Rumah Tangga }\end{array}$} & \multicolumn{2}{c}{ Desa Tanjang } & \multicolumn{2}{c}{ Desa Kosekan } \\
\cline { 2 - 6 } & $\begin{array}{c}\text { Jumlah } \\
(\text { Orang) }\end{array}$ & $\begin{array}{c}\text { Persentase } \\
(\boldsymbol{\%})\end{array}$ & $\begin{array}{c}\text { Jumlah } \\
\text { (Orang) }\end{array}$ & $\begin{array}{c}\text { Persentase } \\
(\boldsymbol{\%})\end{array}$ \\
\hline 25-30 tahun & 0 & 0 & 0 & 0 \\
31-40 tahun & 3 & 6,25 & 3 & 7,32 \\
41-50 tahun & 9 & 18,75 & 5 & 12,20 \\
51-60 tahun & 15 & 31,25 & 10 & 24,39 \\
$>60$ tahun & 21 & 43,75 & 23 & 56,10 \\
\hline
\end{tabular}

Sumber : Pengolahan Data (2017)

Mayoritas responden di Desa Tanjang berada di rentang usia produktif, sedangkan untuk responden Desa Kosekan lebih banyak berada di rentang usia non produktif. Usia produktif merupakan usia yang berada di rentang 15-64 tahun (BPS Kab. Pati, 2017).

Arida dkk (2015) menyatakan bahwa umur rata-rata yang tergolong muda dan masih tergolong umur produktif (15-64 tahun) dapat mengerjakan pekerjaan usahanya dengan maksimal sehingga dapat mencukupi kebutuhan rumah tangganya. Hal ini akan berpengaruh terhadap tanggungan beban

rumah tangga. Fathonah dkk (2011) juga menyatakan bahwa beban tanggungan pada rumah tangga yang tidak berada pada usia produktif lebih besar dibandingkan beban tanggungan pada rumah tangga yang produktif.

Jika dilihat dari persentase jumlah usia produktif, maka beban yang harus ditanggung oleh rumah tangga Desa Kosekan lebih besar dibandingkan beban yang harus ditanggung oleh rumah tangga Desa Tanjang.Karakteristik rumah tangga responden berdasarkan jenis kelamin kepala rumah tangga disajikan pada Tabel 2.

Tabel 2.

Karakteristik Rumah Tangga Responden Berdasarkan Jenis Kelamin Kepala Rumah Tangga

\begin{tabular}{lcccc}
\hline \multirow{2}{*}{$\begin{array}{c}\text { Karakteristik } \\
\text { Rumah Tangga }\end{array}$} & \multicolumn{2}{c}{ Desa Tanjang } & \multicolumn{2}{c}{ Desa Kosekan } \\
\cline { 2 - 5 } & $\begin{array}{c}\text { Jumlah } \\
\text { (Orang) }\end{array}$ & $\begin{array}{c}\text { Persentase } \\
(\boldsymbol{\%})\end{array}$ & $\begin{array}{c}\text { Jumlah } \\
\text { (Orang) }\end{array}$ & $\begin{array}{c}\text { Persentase } \\
(\boldsymbol{\%})\end{array}$ \\
\hline Laki-laki & 39 & 81,25 & 11 & 26,83 \\
Perempuan & 9 & 18,75 & 30 & 73,17 \\
\hline
\end{tabular}

Sumber : Pengolahan Data (2017) 
Karakteristik rumah tangga responden berdasarkan jenis kelamin kepala rumah tangga menunjukkan bahwa mayoritas kepala keluarga di Desa Tanjang adalah laki-laki. Kondisi sebaliknya terjadi di Desa Kosekan yang menunjukkan bahwa mayoritas kepala keluarga adalah perempuan.

Kasimin (2015) menyatakan bahwa sebagian besar manusia yang hidup dalam kemiskinan adalah perempuan, karena keterbatasan akses ekonomi, sosial dan politik serta sumberdaya. Akibat keterbatasan ini akan berdampak negatif pada perkembangan anak dan keluarga. Dewasa ini seperempat dari jumlah rumah tangga diseluruh dunia dikepalai oleh perempuan, dimana empat perlima dari mereka adalah janda dan sepersepuluh dari mereka adalah rumah tangga miskin.

Karakteristik rumah tangga responden berdasarkan tingkat pendidikan kepala rumah tangga disajikan pada Tabel 3.

Tabel 3.

Karakteristik Rumah Tangga Responden Berdasarkan Tingkat Pendidikan Kepala Rumah Tangga

\begin{tabular}{ccccc}
\hline $\begin{array}{c}\text { Karakteristik } \\
\text { Rumah Tangga }\end{array}$ & \multicolumn{2}{c}{ Desa Tanjang } & \multicolumn{2}{c}{ Desa Kosekan } \\
\cline { 2 - 5 } & $\begin{array}{c}\text { Jumlah } \\
\text { (Orang) }\end{array}$ & $\begin{array}{c}\text { Persentase } \\
(\boldsymbol{\%})\end{array}$ & $\begin{array}{c}\text { Jumlah } \\
\text { (Orang) }\end{array}$ & $\begin{array}{c}\text { Persentase } \\
(\boldsymbol{\%})\end{array}$ \\
\hline tidak tamat SD & 7 & 14,58 & 20 & 48,78 \\
SD & 21 & 43,75 & 15 & 36,59 \\
SMP & 15 & 31,25 & 4 & 9,76 \\
SMU & 5 & 10,42 & 2 & 4,88 \\
\hline
\end{tabular}

Sumber : Pengolahan Data (2017)

Karakteristik rumah $\begin{array}{r}\text { tangga } \\ \text { tingkat }\end{array}$
responden berdasarkan
pendidikan kepala rumah
tangga
menunjukkan bahwa persentase tingkat
pendidikan terbesar di Desa Tanjang
adalah SD dan SMP, sedangkan
persentase tingkat pendidikan terbesar di
Desa Kosekan adalah tidak tamat SD dan
SD. Faisal (2013) menyatakan dalam
penelitiannya bahwa tingkat pendidikan
berpengaruh terhadap tingkat kemiskinan
karena pendidikan merupakan salah satu
komponen yang ditekankan dalam
penyebab lingkaran setan kemiskinan.
Tingkat pendidikan berpengaruh
terhadap produktivitas kerja yang
selanjutnya akan mempengaruhi tingkat
kemiskinan.

Karakteristik rumah tangga responden berdasarkan tingkat pendidikan kepala rumah tangga menunjukkan bahwa persentase tingkat pendidikan terbesar di Desa Tanjang adalah SD dan SMP, sedangkan persentase tingkat pendidikan terbesar di Desa Kosekan adalah tidak tamat SD dan SD. Faisal (2013) menyatakan dalam penelitiannya bahwa tingkat pendidikan karena pendidikan merupakan salah satu komponen yang ditekankan dalam penyebab lingkaran setan kemiskinan. tingkat pendidikan berpengaruh selanjutnya akan mempengaruhi tingkat kemiskinan.
Mayoritas kepala rumah tangga responden di Desa Tanjang menunjukkan bahwa tingkat pendapatan berada pada rentang Rp500.000,00 sampai dengan Rp750.000,00. Adapun mayoritas kepala rumah tangga miskin di Desa Kosekan berpendapatan $<$ Rp500.000,00. Tingkat pendapatan erat kaitannya dengan pola konsumsi, dimana tingkat konsumsi akan mempengaruhi tingkat kemakmuran sebuah rumah tangga (Indrianawati, 2015). Upadhyay and Pathania (2013) menyatakan bahwa semakin besar tingkat pendapatan, maka semakin tinggi tingkat pengeluaran untuk konsumsi. Karakteristik rumah tangga responden berdasarkan tingkat pendapatan kepala rumah tangga disajikan pada Tabel 4 . 
Tabel 4.

Karakteristik Rumah Tangga Responden Berdasarkan Tingkat Pendapatan Kepala Rumah Tangga

\begin{tabular}{lcccc}
\hline \multirow{2}{*}{$\begin{array}{c}\text { Karakteristik } \\
\text { Rumah Tangga }\end{array}$} & \multicolumn{2}{c}{ Desa Tanjang } & \multicolumn{2}{c}{ Desa Kosekan } \\
\cline { 2 - 5 } & $\begin{array}{c}\text { Jumlah } \\
\text { (Orang) }\end{array}$ & $\begin{array}{c}\text { Persentase } \\
(\boldsymbol{\%})\end{array}$ & $\begin{array}{c}\text { Jumlah } \\
\text { (Orang) }\end{array}$ & $\begin{array}{c}\text { Persentase } \\
(\boldsymbol{\%})\end{array}$ \\
\hline$<500.000$ & 15 & 31,25 & 32 & 78,05 \\
$500.000-750.000$ & 21 & 43,75 & 6 & 14,63 \\
$750.001-1.000 .000$ & 10 & 20,83 & 2 & 4,88 \\
$>1.000 .000$ & 2 & 4,17 & 1 & 2,44 \\
\hline
\end{tabular}

Sumber : Pengolahan Data (2017)

Acuan penentuan rumah tangga miskin dalam studi ini tidak berdasarkan besar pendapatan rumah tangga namun berdasarkan variabel-variabel BDTTNP2K. Variabel yang digunakan oleh BDT-TNP2K yaitu (1) status kepemilikan bangunan tempat tinggal; (2) status kepemilikan lahan tempat tinggal; (3) jenis lantai terluas; (4) jenis dinding terluas; (5) jenis atap terluas; (6) kualitas dinding terluas; (7) kualitas atap terluas; (8) partisipasi sekolah; (9) kelas tertinggi; (10) ijasah tertinggi; (11) lapangan usaha dari pekerjaan utama; (12) status kedudukan dari pekerjaan utama; (13) sumber air minum; (14) penggunaan fasilitas buang air besar; (15) jenis kloset; (16) tempat pembuangan air tinja; (16) jenis cacat; (17) penyakit kronis/menahun; (18) sumber penerangan utama; (19) daya listrik terpasang (PLN); (20) bahan bakar untuk memasak; (21) kepemilikan tabung LPG 5,5 kg atau lebih; (22) kepemilikan sambungan telepon (PSTN). Kategori rumah tangga miskin menurut BDTTNP2K dibagi menjadi 4 yaitu (1) rentan miskin; (2) hampir miskin; (3) miskin; dan (4) sangat miskin.

\section{Tingkat Ketahanan Pangan Rumah Tangga Miskin di Desa Tanjang dan Desa Kosekan}

Perhitungan tingkat ketahanan pangan rumah tangga miskin di Desa
Tanjang diperoleh hasil bahwa indeks ketahanan pangan rumah tangga miskin di Desa Tanjang sebesar 5,15 yang termasuk kategori rumah tangga tahan pangan. Namun, dari 48 responden terdapat satu responden yang indeks tingkat ketahanan pangan rumah tangganya berada antara 25-50 sehingga responden tersebut tingkat ketahanan pangan rumah tangganya termasuk kategori rumah tangga rawan pangan tanpa kelaparan.

Adapun perhitungan tingkat ketahanan pangan rumah tangga miskin di Desa Kosekan diperoleh hasil indeks 13,84. Indeks ini menunjukkan bahwa rumah tangga miskin di Desa Kosekan termasuk kategori rumah tangga miskin tahan pangan. Diantara 41 responden penelitian di Desa Kosekan, terdapat 4 responden yang indeks tingkat ketahanan pangan rumah tangga miskin berada antara 25-50, yang berarti termasuk kategori rumah tangga miskin rawan pangan tanpa kelaparan. Selain itu, terdapat juga 2 responden yang indeks tingkat ketahanan pangan rumah tangga miskin berada antara 51-75, berarti termasuk kategori rumah tangga rawan pangan dengan tingkat kelaparan sedang. Tingkat ketahanan pangan rumah tangga miskin di Desa Tanjang dan Desa Kosekan disajikan pada Tabel 5. 
Tabel 5.

Tingkat Ketahanan Pangan Rumah Tangga Miskin

di Desa Tanjang dan Desa Kosekan

\begin{tabular}{llrrrr}
\hline \multirow{2}{*}{ No } & \multicolumn{1}{c}{ kategori } & \multicolumn{2}{c}{ Desa Tanjang } & \multicolumn{2}{c}{ Desa Kosekan } \\
\cline { 3 - 6 } & & $\begin{array}{c}\text { Jumlah } \\
\text { (orang) }\end{array}$ & $\begin{array}{c}\text { Persentase } \\
(\boldsymbol{\%})\end{array}$ & $\begin{array}{c}\text { Jumlah } \\
(\text { orang) }\end{array}$ & $\begin{array}{c}\text { Persentase } \\
(\boldsymbol{\%})\end{array}$ \\
\hline 1 & Tahan pangan & 47 & 97,92 & 35 & 85,37 \\
2 & Rawan pangan tanpa kelaparan & 1 & 2,08 & 4 & 9,76 \\
3 & Rawan pangan dg tngkt kelaparan sedang & 0 & 0,00 & 2 & 4,88 \\
4 & Rawan pangan dg tngkt kelaparan lebih & 0 & 0,00 & 0 & 0,00 \\
& parah & & & & \\
\hline
\end{tabular}

Sumber : Pengolahan Data (2017)

Perhitungan tingkat ketahanan pangan rumah tangga miskin di Desa Tanjang dan Desa Kosekan dengan menggunakan metode CPS Food Security Supplement. CPS Food Security Supplement menanyakan tentang bermacam kondisi kejadian perilaku dan reaksi subjektif berupa: (1) kejadian mengurangi konsumsi orang dewasa dalam rumah tangga, atau berbagai akibat yang muncul dari mengurangi asupan makanan, (2) kejadian mengurangi makanan atau berbagai akibat yang muncul karena mengurangi asupan makanan pada anak-anak dalam rumah tangga, (3) kekhawatiran bahwa anggaran pangan rumah tangga atau ketersediaan pangan kemungkinan tidak mencukupi, dan (4) persepsi bahwa konsumsi orang dewasa atau anak-anak dalam rumah tangga tidak mencukupi dari segi kualitas (Fathonah \& Prasodjo, 2011).

Perilaku yang dilakukan pada metode CPS Food Security Supplement erat kaitannya dengan pola konsumsi rumah tangga, dengan kata lain tingkat ketahanan pangan rumah tangga tergantung dari kemampuan konsumsi rumah tangga. Ariani dkk (2002) dalam penelitiannya menyatakan dari proporsi pengeluaran pangan dapat diungkapkan bahwa semakin tinggi proporsi pengeluaran pangan berarti tingkat kesejahteraan atau ketahanan pangan rumah tangga semakin rendah atau rentan. Hal serupa diungkapkan oleh Saputri dkk (2016) yang menyatakan bahwa secara umum tingkat pendapatan mempengaruhi pola dan tingkat pengeluaran rumah tangga. Suatu rumah tangga akan mengalokasikan pendapatannya untuk pangan, setelah itu kebutuhan yang lain. Jika pendapatan yang diperoleh tidak mencukupi untuk membeli bahan pangan, maka risiko untuk menjadi rawan pangan menjadi semakin tinggi. Lebih lanjut Suyastiri (2008) dalam penelitiannya menyatakan bahwa pangan pokok merupakan kebutuhan primer yang harus dipenuhi setiap orang pada berbagai tingkat pendapatan. Pendapatan merupakan faktor utama yang menentukan perilaku rumah tangga dalam melakukan pola konsumsi pangan. Kusumawati dkk (2013) menyebutkan bahwa besar kecilnya pendapatan akan mempengaruhi jenis pangan yang dikonsumsi. Pangan yang dikonsumsi dipengaruhi pola konsumsi pangan dalam rumah tangga. Pola konsumsi pangan rumah tangga ditentukan oleh harga, kebiasaan, pendapatan dan selera.

Secara garis besar kondisi rumah tangga miskin di Desa Tanjang mampu memenuhi kebutuhan pangan rumah tangganya dan mampu menyediakan anggaran yang cukup untuk kebutuhan pangan rumah tangganya. Fathonah dan Prasodjo (2011) menyebutkan bahwa 
tingkat pendapatan rumah tangga yang termasuk dalam kategori rendah mengakibatkan rumah tangga menjadi tidak tahan pangan. Berdasarkan tingkat pendapatan, mayoritas responden Desa Tanjang mempunyai pendapatan $\geq$ Rp500.000,00 dan hanya terdapat 15 responden di Desa Tanjang yang pendapatannya $<$ Rp500.000,00 sehingga secara umum rumah tangga miskin di Desa Tanjang menjadi rumah tangga miskin yang tahan pangan.

Sama halnya dengan kondisi rumah tangga miskin di Desa Tanjang, rumah tangga miskin di Desa Kosekan juga mampu memenuhi kebutuhan pangan rumah tangganya dan mampu menyediakan anggaran yang cukup untuk kebutuhan pangan rumah tangganya. Jika dilihat dari tingkat pendapatan, mayoritas responden <Rp500.000,00. Namun, rumah tangga responden mampu memenuhi kebutuhan pangannya. Hal ini dikarenakan responden mayoritas berusia >50 tahun mayoritas dan sudah tidak mempunyai anak yang harus ditanggung sehingga mengurangi beban yang harus ditanggung keluarga untuk mencukupi kebutuhan pangannya. Selain itu, mayoritas resonden tidak memiliki pekarangan rumah. Rhoyani dkk (2016) menyebutkan bahwa besarnya pengeluaran pangan dipengaruhi oleh pendapatan petani, jumlah tanggungan keluarga, dan luas lahan yang dimiliki.

\section{Ketimpangan Ketahanan Pangan Rumah Tangga Miskin di Desa Tanjang dan Desa Kosekan}

Berdasarkan perhitungan indeks ketahanan pangan rumah tangga miskin diperoleh hasil bahwa kedua desa (Desa tanjang dan Desa Kosekan) termasuk kategori rumah tangga miskin tahan pangan. Analisis secara statistik dilakukan terhadap indeks ketahanan pangan kedua desa untuk menganalisis terdapat tidaknya ketimpangan ketahanan pangan rumah tangga miskin di Desa Tanjang dan Desa Kosekan melalui tingkat signifikansinya. Uji Asumsi Dasar dilakukan sebelum melakukan uji terhadap indeks ketahanan pangan Desa Tanjang dan Desa Kosekan. Uji asumsi dasar yang dilakukan yaitu uji normalitas dan uji homogenitas.

Tabel 6.

Uji Normalitas Ketahanan Pangan Rumah Tangga

Desa Tanjang dan Desa Kosekan

\begin{tabular}{llllllll}
\hline & \multirow{2}{*}{ desa } & \multicolumn{3}{l}{ Kolmogorov-Smirnov $^{\mathrm{a}}$} & \multicolumn{5}{l}{ Shapiro-Wilk } \\
\cline { 3 - 8 } & & Statistic & df & Sig. & Statistic & df & Sig. \\
\hline \multirow{2}{*}{ indeks } & tanjang & 0,209 & 48 & 0,000 & 0,885 & 48 & 0,000 \\
& kosekan & 0,189 & 41 & 0,001 & 0,831 & 41 & 0,000 \\
\hline
\end{tabular}

a. Lilliefors Significance Correction

Sumber : Pengolahan Data (2017)

Uji normalitas digunakan untuk mengetahui apakah populasi data berdistribusi normal atau tidak. Uji yang digunakan yaitu uji one sample Kolmogorov-Smirnov dan uji ShapiroWilk dengan menggunakan taraf signifikansi 0,05. Data berdistribusi normal jika signifikansi $>0,05$ atau $5 \%$.
Nilai sig. uji one sample Kolmogorov-Smirnov untuk indeks Desa Tanjang adalah 0,000 dan untuk indeks Desa Kosekan adalah 0,001 menunjukkan $<0,05$ sehingga data tidak terdistribusi normal. Hasil uji ShapiroWilk untuk indeks Desa Tanjang adalah 0,000 dan untuk indeks Desa Kosekan 
adalah $\quad 0,000$ menunjukkan $<0,05$ sehingga data tidak terdistribusi normal.

Uji homogenitas digunakan untuk mengetahui apakah beberapa varian populasi adalah sama atau tidak. Uji ini dilakukan sebagai prasyarat dalam analisis independent sample T-Test dan ANOVA. Asumsi yang mendasari dalam analisis varian (ANOVA) adalah bahwa varian dari populasi adalah sama. Kriteria pengujian, apabila nilai signifikansi $>0,05$ maka dapat dikatakan bahwa varian dari dua/ lebih kelompok data adalah sama.

\section{Tabel 7.}

Uji Homogenitas Ketahanan Pangan Rumah Tangga Desa Tanjang dan Desa

$$
\text { Kosekan }
$$

indeks

\begin{tabular}{llll}
\hline Levene Statistic & df1 & df2 & Sig. \\
\hline 15,931 & 1 & 87 & 0,000 \\
\hline
\end{tabular}

Sumber : Pengolahan Data, 2017

Nilai signifikansi sebesar 0,000 menunjukkan nilai $<0,05$ sehingga indeks ketahanan pangan Desa Tanjang dan Desa Kosekan mempunyai varian tidak sama. Angka Levene Statistic menunjukkan semakin kecil maka semakin besar homogenitasnya. Angka Levene Statistic dari indeks ketahanan pangan Desa Tanjang dan Desa Kosekan sebesar 15,931 menunjukkan bahwa homogenitas indeks ketahanan pangan kedua desa semakin kecil. Jika data yang diuji tidak terdistribusi normal dan tidak homogen maka digunakan metode statistik non parametrik dengan uji Mann Whitney (Tabel 8).

Hasil uji Mann Whitney pada Tabel 8 menunjukkan bahwa probabilitas (sig) sebesar 0,000. Oleh karena nilai probabilitas $<0,05$; maka $\mathrm{H}_{0}$ diterima, artinya tingkat ketahanan pangan di Desa Tanjang dan Desa Kosekan sama atau tidak berbeda nyata (tidak signifikan). Tingkat ketahanan pangan baik di Desa
Tanjang maupun Desa Kosekan tidak signifikan berbeda karena fokus penelitian adalah rumah tangga miskin di daerah yang rawan banjir.

Tabel 8.

Hasil Uji Mann Whitney Tingkat

Ketahanan Pangan Desa Tanjang dan Desa Kosekan

\begin{tabular}{lr}
\hline & \multicolumn{1}{c}{ indeks } \\
\hline Mann-Whitney U & 519,000 \\
Wilcoxon W & $1,695 \mathrm{E} 3$ \\
Z & $-3,838$ \\
Asymp. Sig. (2-tailed) & 0,000 \\
\hline
\end{tabular}

a. Grouping Variable: desa

Sumber : Pengolahan Data, 2017

Baik Desa Tanjang maupun Desa Kosekan merupakan daerah rawan banjir, yang membedakan adalah Desa Tanjang telah ditetapkan sebagai salah satu Desa Tangguh Bencana (Destana) sedangkan Desa Kosekan belum ditetapkan sebagai Destana. Penetapan Destana ini merupakan salah satu program yang dilaksanakan oleh BPBD Kabupaten Pati dalam upaya penanggulangan bencana (khususnya banjir) di Kabupaten Pati. Walaupun berbeda status dalam hal kesiapsiagaan penanggulangan bencana, namun tingkat ketahanan pangan rumah tangga miskinnya tidak berbeda nyata (dibuktikan dengan uji beda). Besarnya pengeluaran pangan dipengaruhi oleh pendapatan petani, jumlah tanggungan keluarga dan luas lahan yang dimiliki (Rhoyani dkk, 2016). Hal sama juga dikemukakan dalam penelitian Hasibuan dkk (2014) menyebutkan bahwa faktorfaktor yang mempengaruhi konsumsi pangan sumber karbohidrat non beras adalah pendapatan rumah tangga, jumlah tanggungan, umur dan tingkat pendidikan.

Jika dilihat dari profil responden yang merupakan rumah tangga miskin dapat dilihat bahwa baik untuk Desa Tanjang maupun Desa Kosekan relatif 
sama yaitu mayoritas berumur $>50$ tahun, tingkat pendidikan $\leq \mathrm{SD}$ dan tingkat penghasilan $\leq$ Rp750.000,00. Hal ini yang menyebabkan tidak terjadi ketimpangan ketahanan pangan pada rumah tangga miskin pada kedua desa.

\section{KESIMPULAN DAN SARAN Kesimpulan}

Berdasarkan hasil perhitungan indeks ketahanan pangan rumah tangga miskin di Desa Tanjang dan Desa Kosekan termasuk kategori rumah tangga tahan pangan. Setelah dilakukan uji terhadap indeks ketahan pangan di Desa Tanjang dan Desa Kosekan diperoleh hasil bahwa tingkat ketimpangan pangan Desa Tanjang \& desa Kosekan sama atau tidak berbeda nyata (tidak signifikan).

\section{Saran}

Permasalahan yang dihadapi rumah tangga miskin di lokasi studi adalah pendapatan rumah tangga yang rendah. Menjaga ketahanan pangan rumah tangga perlu dilakukan melalui upaya peningkatan pendapatan rumah tangga. Pemerintah dapat melakukan upaya peningkatan pendapatan rumah tangga miskin dengan cara meningkatkan minat wirausaha melalui pemberian modal kerja dan pembinaan bagi rumah tangga miskin yang berusaha di sektor informal bagi usia produktif. Bagi usia tidak produktif dapat melakukan sosialisasi dan pemanfaatan lahan pekarangan (program Rumah Hijau) sekitar tempat tinggal guna memenuhi kebutuhan pangan rumah tangga.

\section{DAFTAR PUSTAKA}

Ariani, M., Purwantini, T. B. (2002). Analisis Konsumsi Pangan Rumah Tangga Pasca Krisis Ekonomi di Propinsi Jawa Barat. SOCA: Socioeconomics of Agriculture and Agribusiness, 6(1), 1-16.

Arida, A., Sofyan., Fadhiela, K. (2015). Analisis Ketahanan Pangan Rumah
Tangga Berdasarkan Proporsi Pengeluaran Pangan dan Konsumsi Energi. Agrisep, 16(1), 20-34.

Association of Maternal and Child Health Programs. (2013). Life Course Indicator : Household Food Insecurity. The Life Course Metrics Project. Washington

Badan Penanggulangan Bencana Daerah Kabupaten Pati. (2017). Laporan Bencana Banjir Tahun 2017. Pati : BPBD Kabupaten Pati.

Badan Pusat Statistik Kabupaten Pati. (2017). Pati Dalam Angka Tahun 2016. Pati : BPS Kabupaten Pati.

Ermawati, R. O. (2011). Analisis Ketahanan Pangan Rumah Tangga Miskin pada Daerah Rawan Banjir di Kecamatan Jebres Kota Surakarta. Skripsi. Fakultas Pertanian. Surakarta : Universitas Sebelas Maret.

Faisal, H. (2013). Pengaruh Tingkat Pendidikan, Kesehatan Terhadap Produktivitas dan Jumlah Penduduk Miskin di Provinsi Kalimantan Barat. Tesis. Program Magister Ilmu Ekonomi Fakultas Ekonomi. Pontianak : Universitas Tanjung Pura.

Fathonah, T. Y., Prasodjo, N. W. (2011). Tingkat Ketahanan Pangan pada Rumah Tangga yang Dikepalai Pria dan Rumah Tangga yang Dikepalai Wanita. Jurnal Transdisiplin Sosiologi, Komunikasi, dan Ekologi Manusia, 5(3), 197-216.

Hasan, Y., Saputra. W. (2008) Ketahanan pangan dan kemiskinan: Implementasi dan kebijakan penyesuaian. Jurnal Ipteks Terapan, 2(1), 146-168.

Hasibuan, M. Lubis, S. N., Ginting, R. (2014). Analisis Pola Konsumsi 
Pangan Non Beras Sumber Karbohidrat di Kecamatan Medan Tuntungan. Journal on Social Economic of Agriculture and Agribusiness, 3(10), 1-11.

Indrianawati, E. (2015). Pengaruh Tingkat Pendapatan dan Pengetahuan Ekonomi Terhadap Tingkat Konsumsi Mahasiswa Program Pascasarjana Universitas Negeri Surabaya. Jurnal Ekonomi Pendidikan dan Kewirausahaan, 3(1), 214-226.

Kasimin, S. (2015). Indikator Sosial Ekonomi Wilayah dan Ketahanan Pangan Rumah Tangga Perempuan Miskin Aceh. Agrisep, 16(1), 1-9.

Kusumawati, T. D. Marwanti, S., Ani, S. W. (2013). Analisis Ketersediaan Pangan Pokok dan Pola Konsumsi Pangan Rumah Tangga Petani di Kecamatan Nogosari Kabupaten Boyolali.

http://agribisnis.fp.uns.ac.idwpcontentuploads201401JurnalTRIASTUTI-DEWI-KUSUMA WATI- H0809110.pdf : 1-12.

Nurhemi. Soekro, S. R. I., Suryani, G. (2014). Pemetaan Ketahanan Pangan di Indonesia : Pendekatan TFP dan Indeks Ketahanan Pangan. Working Paper. Jakarta : Bank Indonesia.

Pemerintah Republik Indonesia. (2012). Undang-undang Republik Indonesia Nomor 18 Tahun 2012 tentang Pangan. Jakarta : Pemerintah Republik Indonesia.

Rhoyani, I., Rahayu, E. S., Ani, S. W. (2016). Analisis Ketahanan Pangan Rumah Tangga Petani di Sub Daerah Aliran Sungai (DAS) Keduang Kabupaten Wonogiri. AGRISTA, 4(2), 31-42.

Rosyadi, I., Purnomo, D. (2012). Tingkat Ketahanan Pangan Rumah Tangga di Desa Tertinggal. Jurnal Ekonomi Pembangunan, 13(2), 303-315.

Saputri, R., Lestari, L. A., Susilo, J. (2016). Pola Konsumsi Pangan dan Tingkat Ketahanan Pangan Rumah Tangga di Kabupaten Kampar Provinsi Riau. Jurnal Gizi Klinik Indonesia, 12(3), 123-130.

Suyastiri, N. M. (2008). Diversifikasi Konsumsi Pangan Pokok Berbasis Potensi Lokal Dalam Mewujudkan Ketahanan Pangan Rumah Tangga Pedesaan di Kecamatan Semin Kabupaten Gunung Kidul. Jurnal Ekonomi Pembangunan, 13(1), 5160.

Upadhyay, H., Pathania, R. (2013). Consumer Expenditure Behavior in India: a Case of Rural and Urban Consumer. International Journal of Business and Management Invention, 2(2), 6873.

Widayaningsih, N. (2012). Ketahanan Pangan pada Rumah Tangga Miskin (Perbandingan Kasus di Perdesaan dan Perkotaan Kabupaten Banyumas). Jurnal Pembangunan Pedesaan, 12(1), 45-55.

Zakari, S., Ying, L., Song, B. (2014). Factors Influencing Household Food Security in West Africa: The Case of Southern Niger. Sustainability, 6, 1191-1202

\section{BIODATA PENULIS}

Herna Octivia Damayanti, lahir 6 Oktober 1985 di Kudus Jawa Tengah. Pendidikan Magister Manajemen Sumberdaya Pantai Universitas Diponegoro. Saat ini bekerja sebagai Peneliti di Badan Perencanaan Pembangunan Daerah Kabupaten Pati 